\title{
En formel vs. en funktionel tilgang til dansk sætningsstruktur
}

\author{
STEN VIKNER \& HENRIK JØRGENSEN
}

\begin{abstract}
Diderichsen (1946: 186) foreslår to sætningsskemaer til analyse af sætningsstrukturen i dansk. I Diderichsens (1946) hovedsætningsskema består en dansk hovedsætning af tre felter som igen består af tilsammen syv pladser. I den generative struktur som vi her vil gå ind for, er der langt flere underinddelinger end der er felter og pladser hos Diderichsen (1946). En anden forskel er at der er mere asymmetri i den generative analyse: Diderichsen (1946) har mange konstituenter på samme niveau hvorimod den generative analyse grundlæggende opererer med binære strukturer. Vi vil vise hvorledes det større analytiske apparat tillader interessante generaliseringer og forudsigelser i den generative analyse som ikke er mulige $\mathrm{i}$ et sætningsskema. Udover disse forskelle vil vi også beskæftige os med tre paralleller mellem de to tilgange, nemlig Diderichsens skelnen mellem topologi og syntaks, Diderichsens tre overordnede felter og hvad de svarer til i den generative analyse, og endelig også ideen om flytning af konstituenter i sætningsstrukturen. En del af vores konklusion vil være at alle syntaktikere/grammatikere burde være parat til at tage både de generative og de funktionelle tilgange alvorligt. Selvom tonen nogle gange kan være lidt polemisk, har de forskellige tilgange så meget til fælles at de uden ret stort besvær kan lære en del af hinandens resultater og erkendelser.
\end{abstract}

EMNEORD: funktionel sætningsanalyse, generativ sætningsanalyse, sætningsskema, træstrukturer, konstituent, c-kommando 


\section{INDLEDNING: GENERATIVE TRÆER OG DIDERICH- SENS FELTER}

I denne artikel vil vi diskutere forholdet mellem en funktionel og en formel tilgang til dansk sætningsstruktur gennem en sammenligning af Paul Diderichsens sætningsskema ${ }^{1}$ med en generativ analyse. Vi vil illustrere at Diderichsens analyse har store fordele, men at den generative grammatik tilbyder yderligere en række fordele.

Selv om Paul Diderichsens analyse ikke uden videre kan betragtes som en funktionel analyse, vil vi dog hævde at hans opfattelse af syntaksen rummer klart funktionelle aspekter, sml. afsnit 1.1 nedenfor. Vores synspunkt på modsætningen mellem funktionel og formel sprogbeskrivelse er - meget firkantet sagt - at der er tale om en pseudomodsætning hvis man holder sig til det rent deskriptive plan; som vi skal vise, er en væsentlig del af forskellene rene notationsforskelle. Både den formelle og den funktionelle tilgang er bestemt af de generelle vilkår for en videnskabelig tilgang. Sproget befinder sig inde i kybernetikkens sorte boks, dvs. en mekanisme som vi som forskere ikke har direkte adgang til, og begge tilgange er derfor nødt til at betjene sig af manipulationer $i$ input og output for at kunne se hvad der foregår inde i boksen. Det medfører at begge tilgange er afhængige af klassiske strukturalistiske testmetoder (fx kommutationsprøven) for at kunne udforske genstanden. Der hvor den funktionelle og den formelle tilgang for alvor går hver sin vej, handler det i virkeligheden ikke om selve den konkrete beskrivelse af sproglige forhold, men om det synspunkt man anlægger på sproget. I den funktionelle tilgang vil man - meget forenklet - gerne se sproget som bestemt af tilpasningen til den kommunikative funktion, mens man i den formelle tilgang lægger mere vægt på at se sproget og sprogevnen som determineret af den menneskelige hjerne og dennes begrænsninger.

Lad os nu gå over til de mere konkrete aspekter af forskellene mellem de to tilgange. Diderichsen (1946: 186) foreslår to sætningsske-

1 I denne artikel forholder vi os først og fremmest til Diderichsens (1946) egen analyse, idet vi mener at der er en lang række analyser af dansk der ikke blot har deres udspring i men også kan repræsenteres af Diderichsen (1946). Sådanne analyser inkluderer følgende (som der dog også bliver refereret direkte til forskellige steder nedenfor): Becker-Christensen (2010), Blom (2006), Hansen (1977), Hansen \& Heltoft (2011), Jørgensen (2000), Lundskær-Nielsen et al. (2010) og Togeby (2003). 
maer, som senere også er blevet anvendt af mange andre, til dels i modificeret form. Ifølge Diderichsens (1946) hovedsætningsskema består en dansk hovedsætning af tre felter som igen består af tilsammen syv pladser, jf. (1b-c). I en generativ struktur er der langt flere underinddelinger, se (1)a, end der er felter og pladser hos Diderichsen (1946), se (1)b-c, og vi vil forsøge at vise at dette er en fordel snarere end det modsatte, idet vi mener der er brug for flere og andre underinddelinger (eller flere og andre felter og pladser) end dem Diderichsens analyse (og hans efterfølgeres analyser) kan tilbyde. Et eksempel kan være at kun den generative analyse har en underinddeling som indeholder hovedverbet plus objektet plus det slutstillede adverbial (hovedverbets VP: Jeg har altid gerne villet kunne snakke ordentligt tysk uden at lave fejh), hvorimod Diderichsen har en underinddeling som indeholder alle infinitte verber ( $\mathbf{V}$-pladsen: Jeg har altid gerne villet kunne snakke ordentligt tysk uden at lave fej). Vi vil vise i afsnit 2.1 og 2.2 hvorledes dette leder til forskellige forudsigelser i forhold til de strukturtests som er alment anerkendt inden for begge slags tilgange.

En anden forskel er at der er mere asymmetri i den generative analyse: Diderichsen (1946) har mange konstituenter på samme niveau, jf. at både subjektet og objektet befinder sig på 3 . niveau under sætningsniveauet (1. sætningen - 2. felterne - 3. pladserne). Den generative analyse har derimod meget få konstituenter der er på helt samme niveau, fx vil subjektet næsten altid være langt højere oppe i strukturen end objektet ( $\mathrm{fx}$ 3. niveau under sætningsniveauet vs. 11. niveau under sætningsniveauet) (jf. Peter og bilen i analysen i (1)). Denne asymmetri benyttes i den generative grammatik til at beskrive en lang række relationer mellem konstituenter, $\mathrm{fx}$ forholdet mellem negationen og negative polaritetselementer, mellem antecedenten og et koreferentielt personligt pronomen, eller mellem antecedenten og et refleksivt pronomen. I den slags forhold er det den lodrette dimension der muliggør et effektivt og økonomisk beskrivelsesapparat, den såkaldte "c-command" (se nedenfor). Det er formentlig meget sværere at formulere denne type af strukturelle betingelser $i$ et sætningsskema. Vi behandler denne forskel i afsnit 2.3.

Endnu en forskel er at den generative tilgang bruger den samme struktur til at analysere både hoved- og bisætninger, hvorimod Dide- 
richsen (1946: 186) har to forskellige strukturer (sætningsskemaer). Den behandles nedenfor $i$ afsnit 2.4 .

Ud over disse forskelle vil vi også diskutere nogle paralleller mellem de to tilgange, nemlig Diderichsens tre overordnede felter og hvad de svarer til i den generative analyse (afsnit 3.1), Diderichsens skelnen mellem topologi og syntaks (afsnit 3.2), og endelig også ideen om at konstituenter kan flytte fra et sted i sætningsstrukturen til et andet (afsnit 3.3). Inden vi går i gang med det ovenfor skitserede program, vil vi begynde med at diskutere den måske allermest synlige forskel mellem de to tilgange. Ved en gennemgang af den nyere syntaktiske forskning kunne det nemlig se ud som om følgende forskel mellem forskellige tilgange til sætningens struktur må være helt central:

- tra-analyser, som fx dem der anvendes bl.a. i den generative lingvistik (fx Chomsky 1986 og mange andre), se (1)a.

- felt-analyser, som fx de to satningsskemaer i Diderichsen $(1946,1964)$ og mange andre eller som den topologische Modelli Drach (1937) og mange andre, se (1)b,c.

Vi vil imidlertid hævde at forskellen mellem træ-analyser og felt-analyser ikke udgør en særlig væsentlig forskel mellem de to tilgange. Der er tværtimod kun tale om en notationsforskel.

Én måde at analysere dansk sætningsstruktur er altså den generative trastruktur i (1)a (se også afsnit 1.2 nedenfor). En anden måde er Diderichsens (1946: 186) satningsskemaer, som i (1)b for hovedsætninger og $\mathrm{i}$ (1)c for bisætninger (se også Bjerre et al. 2008 og afsnit 1.1 nedenfor). 
(1) a.

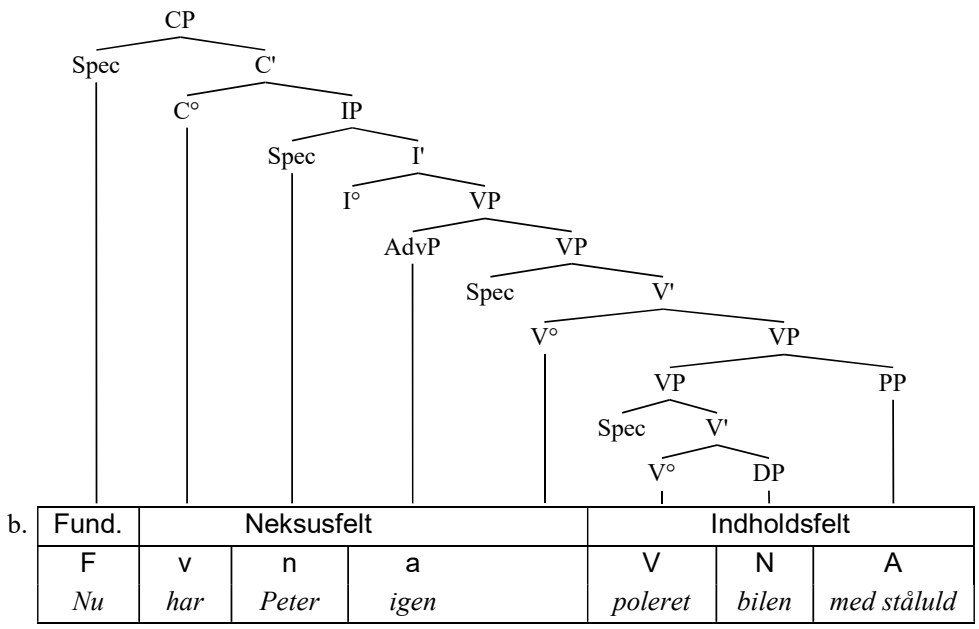

c.

\begin{tabular}{|c|c|c|c|c|c|c|c|}
\hline \multicolumn{2}{|c|}{ Konj. felt } & \multicolumn{3}{|c|}{ Neksusfelt } & \multicolumn{3}{c|}{ Indholdsfelt } \\
\hline$(\mathrm{F})$ & $\mathrm{k}$ & $\mathrm{n}$ & $\mathrm{a}$ & $\mathrm{v}$ & $\mathrm{V}$ & $\mathrm{N}$ & $\mathrm{A}$ \\
& om & Peter & igen & har & poleret & bilen & med ståluld \\
\hline
\end{tabular}

Forskellen er bl.a. i hvor høj grad de forskellige konstituenter ${ }^{2}$ i sætningen ses som dele af andre konstituenter ("æsker inden i andre æsker") eller som følgende efter andre konstituenter ("perler på en snor"). Som man kan se i (1)a-c, er dette ikke et enten-eller spørgsmål, idet der i begge tilgange er konstituenter der forekommer ved siden af andre konstituenter, og idet der i begge tilgange er konstituenter der forekommer inden $i$ andre konstituenter: Selv for analyser som Diderichsen (1946) eller Drach (1937) står nogle konstituenter inden i andre konstituenter

2 Vi anvender konstituent i ordets generelle betydning "bestanddel", dvs. en af de dele som noget består af (jf. Retskrivningsordbogen 2012 og Den Danske Ordbog 2003-05). Denne anvendelse findes ikke kun inden for generativ lingvistik, men også i den funktionelle lingvistik, fx Bache \& Davidsen-Nielsen (1997: 20), Preisler (1997: 19), Givón (2001: 110), Hengeveld \& Mackenzie (2008: 16) og Matthiessen \& al. (2010: 76), og den går helt tilbage til den tidlige strukturalisme, se Bloomfield (1933: 160-161). Ikke kun i sætningsskemaerne men også i den generative analyse er der forskel mellem en konstituent og den plads hvor konstituenten står. CP-spec (altså den venstre datter af CP, se fx (1)a) er således en position, helt svarende til fundamentfeltet, og i denne position kan der stå forskellige typer konstituenter, fx en adverbialfrase ( $\underline{N u}$ har Peter igen poleret bilen med stäluld) eller en præpositionalfrase (Uden tvivl har Peter igen poleret bilen med ståluld) eller en bisætning ( med staluld). 
( $f x$ er objektet en del af indholdsfeltet $i$ analysen af dansk og en del af centralfeltet $i$ analysen af tysk); og også for den generative analyse følger nogle konstituenter efter andre (fx følger objektet efter hovedverbet $i$ analysen af dansk).

Den forskel at de to analyser deler en dansk sætning op $\mathrm{i}$ helt forskellige bestanddele (fx IP vs. neksusfelt), er en væsentlig forskel, hvorimod valget af hvordan disse to forskellige opdelinger typisk illustrereres (træ- vs. feltanalyse), ikke er en væsentlig forskel men blot en notationsforskel. At det kun drejer sig om en notationsforskel, kan illustreres af at en generativ træstruktur som den i (1)a kan formuleres som en feltstruktur, som vist i (2)a, ligesom en sætningsskemaanalyse som den i (1)b kan formuleres som en træstruktur, som vist $\mathrm{i}(2) \mathrm{b},{ }^{3}$ uden noget tab af information.

(2) a.

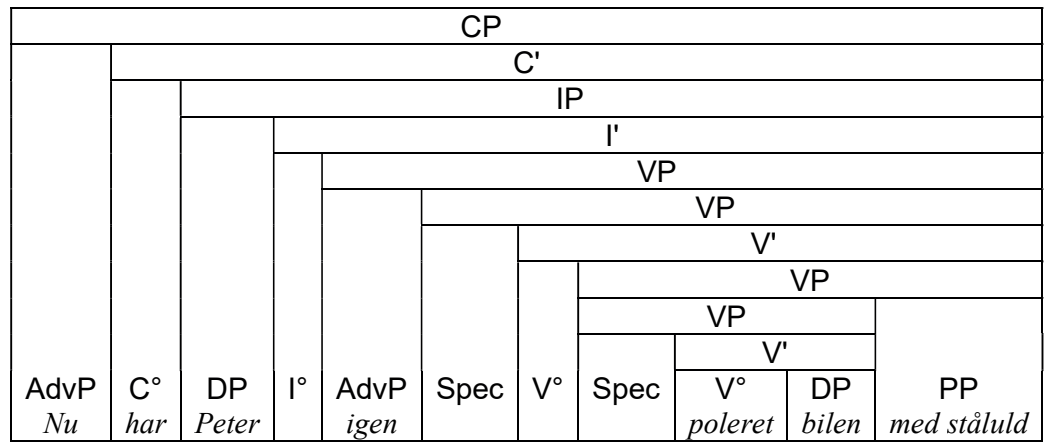

b.

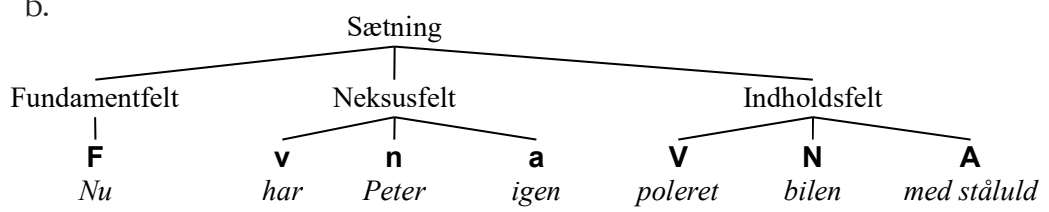

3 (2)b findes tilsvarende hos Brandt (1974: 72). 
Det at (1)a og (2)a indeholder helt den samme information, og at (1)b og (2)b også indeholder helt den samme information, viser klart at forskellen mellem træanalyse og feltanalyse kun er en notationsforskel og ikke en central forskel mellem den generative analyse og Diderichsen (1946).

Helt central er derimod den forskel at der er mange flere konstituenter der er inden $i$ andre konstituenter, i den generative analyse end der er i sætningsskemaerne. Dette giver sig udtryk i at både Diderichsensætningsskemaerne i (1)b,c og Diderichsen-træstrukturen i (2)b er langt fladere end de tilsvarende generative træstrukturer og feltstrukturer $i$ (1)a og (2)a. Grunden er bl.a. at den generative analyse ikke tillader mere end binær forgrening (binary branching), dvs. hver knude i træstrukturen eller hvert felt $\mathrm{i}$ feltstrukturen må højst deles op i to knuder/felter på niveauet nedenunder.

Før vi kommer til forskellene og parallellerne mellem de to analyser, vil vi kort se lidt nærmere på de to tilgange. Hvad Diderichsens sætningsskema angår, er spørgsmålet om denne analyse kan betragtes som en del af en funktionel tilgang til syntaks, og angående den generative analyse ser vi nærmere på nogle af grundantagelserne.

\subsection{Diderichsen som funktionel lingvist}

Her er spørgsmålet som sagt hvorvidt sætningsskemaet hos Paul Diderichsen $(1936,1941,1946,1964)$ kan betragtes som en del af en funktionel tilgang til syntaks. Selv om Diderichsens analyse uden tvivl er den der hyppigst anvendes af funktionelle lingvister i Danmark og Skandinavien, kunne den ved første blik snarere se ud til at være en strukturalistisk analyse. Der ligger et paradoks i at Diderichsen, som påvist af Carol Henriksen (1986), arbejdede med syntaks ud fra de strukturelle principper der blev oparbejdet i 1930 'erne. Hos datidens systemtænkere blev sætningens struktur generelt opfattet som et ususfænomen, altså ikke en regulær genstand for lingvistisk undersøgelse (se Hjelmslev 1972: 57). Diderichsen har været klar over at hans syntaktiske interesse lå i margenen af tidens strukturelle tænkning; hans motivationer, som Carol Henriksen citerer, er derfor ofte funktionelt orienterede, uanset at der mangler en teoretisk funktionel ramme. 
Grundlæggende hviler analysen hos Diderichsen på en række antagelser af hvad sætninger gør i en tekst, dvs. en typisk funktionel analyse. Her er der især to aspekter af Diderichsens analyse der placerer den som en del af den funktionelle tilgang. Den ene er hans fortolkning af overfladestrengen som et middel til at indføre diskurselementer, hvilket udtrykkes i opdelingen af sætningen i felter, hvis navne understreger deres funktion i diskursen: fundamentfeltet, neksusfeltet og indholdsfeltet. Disse illustrerer fordelingen af kontekstuelle funktioner i sætningen, med gammel information først og ny information til sidst i sætningen. Den moderne fortolkning af Diderichsens analyse som funktionel kan ses i følgende citat og udsnit fra Heltoft (1992: 18): 'In Danish topological tradition (Paul Diderichsen's sentence frame) the three main functions of word order correspond by and large to the tripartition of the main clause into socalled fields".

Functional interpretation of Diderichsen's sentence frame

\begin{tabular}{|c|c|c|}
\hline anaphors, theme, focus & reality & $\begin{array}{c}\text { grammatical functions / } \\
\text { semantic content }\end{array}$ \\
\hline fundamental field & actuality (or nexus) field & content field \\
\hline
\end{tabular}

Det andet aspekt af Diderichsens analyse der sikrer affiniteten til en funktionel tilgang, er hans forstålse af hovedsætningen som talehandling. Selv om Diderichsen ikke lod det få nogen direkte indflydelse på hvordan han udformer den konkrete sætningsbeskrivelse, er der i Diderichsen (1939) nedlagt en forståelse af hovedsætningen som svarer til forståelsen af performativen hos Austin (1984). Selvsagt er det ikke Austins talehandlingsbegreb som Diderichsen refererer til, men derimod det ækvivalente fænomenologiske begreb "Setzung" ('sættelse', "hævdelse"), som Diderichsen havde hentet fra Husserl-traditionen. ${ }^{4}$ Han når frem til dette begreb gennem en kritik af den grammatiske traditions omgang med modsætningen mellem indikativ og konjunktiv. I traditionen er disse to grammatiske begreber ofte koblet med spørgsmålet om realitet (angivet ved indikativ) overfor hypotese (angivet ved

4 Diderichsen (1939: 37) nævner Ernst Heller og A. Pfänder som sine kilder; hvad angår Austin, er Husserl-eleven Adolph Reinach ofte blevet nævnt som en inspirationskilde for ham. 
konjunktiv). Her skærer Diderichsen igennem og gør opmærksom på at det afgørende ikke er hvilket forhold sætningen står i til virkeligheden, men derimod om indholdet gøres gældende som aktuelt og relevant i situationen, samt om indholdet bliver forpligtende for den videre udvikling af fremstillingen. Han skriver: "(...) ved at fremsætte et Indhold i Indikativ giver man et Tankeprodukt (der har sin selvstændige "irreale" Existens uafhængigt af den reale skabende psykiske Proces) en "forbindende", "forpligtende" Karakter; man konstituerer det i Udsagnet indeholdte Tankekompleks ("Gedankengebilde") som grundlæggende Fixum for en udtrykt (ell. blot mulig) videre Tankebygning, og udelukker saaledes Gyldigheden af en bestemt Række af Domme eller Antagelser, der strider mod den først "satte"." (Diderichsen 1966: 37). Bemærk at to af de vigtigste pointer ved Austins talehandlingsteori er inkluderet: ytringen skal have en effekt $\mathrm{i}$ konteksten, og ytringen kan ikke vurderes ud fra et sandt/falsk-perspektiv; se Austin (1984). ${ }^{5}$

\subsection{Den generative analyse}

I den version af den generative analyse som vi her fremlægger, har alle syntaktiske konstituenter den samme grundstruktur, som i (4), ofte kaldet "X-bar-struktur":

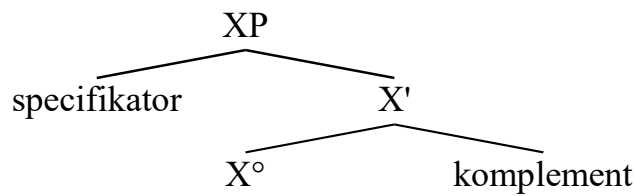

5 Som sagt blev denne diskussion for Diderichsen henvist til at gælde modalitetskategorien. Dens relevans for syntaksen tog Diderichsen derimod aldrig op, og selve observationen er blevet stående i en artikel hvis titel næppe tiltrækker mange interesserede læsere. Ikke desto mindre er det netop her vi finder Diderichsens måske mest afgørende tilnærmelse til en funktionel sprogteori; men det skal villigt indrømmes at han ikke gjorde det særlig let at hente denne pointe frem. Samtænkningen af en Diderichsen-inspireret syntaksbeskrivelse med talehandlingsteorien er gennemført i Heltoft (1992) og i Christensen (2007: 101-102), og den er også et bærende element i Hansen \& Heltoft (2011: 53-64, 1677-1708). 
Der er tre såkaldte projektionsniveauer i (4):

$$
\begin{array}{ll}
\mathrm{XP}=\text { frase }(=\text { syntagme }) & / \text { den maksimale projektion af } \mathrm{X} \\
\mathrm{X}^{\prime}=\mathrm{X} \text {-bar } & / \text { den intermediære projektion af } \mathrm{X} \\
\mathrm{X}^{\circ}=\text { Kerne } & / \text { den minimale projektion af } \mathrm{X} \\
& \begin{array}{l}
\text { (dvs. et ord eller en endnu mindre } \\
\text { enhed })
\end{array}
\end{array}
$$

Det at XP og X' er projektioner af X, udtrykker at disse konstituenter

\begin{tabular}{|c|c|c|c|}
\hline \multicolumn{2}{|c|}{ Leksikalske kategorier (ordklasser) } & \multicolumn{2}{|c|}{ Grammatiske ${ }^{6}$ kategorier } \\
\hline $\begin{array}{l}\mathrm{N} \\
\mathrm{V}\end{array}$ & $\begin{array}{l}\text { (substantiv) } \\
\text { (verbum) }\end{array}$ & $\mathrm{C}$ & $\begin{array}{l}\text { ("complementiser }=\text { underord } \\
\text { nende konjunktion) }\end{array}$ \\
\hline $\mathrm{P}$ & (præposition) & I & (inflektion) \\
\hline Adj & (adjektiv) & $\mathrm{D}$ & $(\text { determiner })^{7}$ \\
\hline $\mathrm{Adv}$ & (adverbium) & m.v. & \\
\hline
\end{tabular}
er bygget op omkring $\mathrm{X}^{\circ}$, således at $\mathrm{fx}\left[_{\mathrm{pP}}\right.$ på en tallerken $]$ er bygget op omkring $\left[\mathrm{p}_{\mathrm{o}} p a\right]$.

X i (4) og (5) kan stå for en af de følgende kategorier:

En kerne er altid kerne i sin egen frase (dens egen maksimale projektion), og alle maksimale projektioner har en kerne (dvs. alle fraser ses som endocentriske). Inden i en frase er der også plads til to andre fraser, nemlig i specifikatorpositionen og i komplementpositionen.

Placeringen af specifikatorpositionen bliver ofte set som invariabel, dvs. den er altid den venstre datter af den pågældende frase. Rækkefølgen mellem kerne og komplement kan derimod variere, alt afhængig

6 I den generative litteratur betegnes disse grammatiske kategorier som 'functional categories'.

7 En determiner som den bliver her set som kernen $\left(\mathrm{D}^{\circ}\right)$ i en determinerfrase (DP) den blà bil. Komplemementet til $\mathrm{D}^{\circ}$ er $\mathrm{NP}^{\prime}$ en blå bil, og kernen $\left(\mathrm{N}^{\circ}\right)$ af denne NP er bil. 
af det enkelte sprog (jf. positionen af objektet bil/ Auto efter verbet på dansk, som i (1), men før verbet på tysk, som i (10)).

Både kerner og fraser (minimale og maksimale projektioner) kan flytte opad i strukturen. Kerner kan kun flytte til andre kernepositioner, og fraser kan kun flytte til andre frasepositioner. X-bar-konstituenter (intermediære projektioner) kan ikke flytte. Typiske forskelle på en bisætning og en hovedsætning på dansk er netop at der $\mathrm{i}$ hovedsætningen er sket flytning af både en kerne (det finitte verbum flytter til $\mathrm{C}^{\circ} / \mathbf{v}$ ) og en frase (en frase, fx subjekt eller objekt, flytter til CP-spec/F; jf. (1).

Både kerner og fraser kan adjungeres til andre konstituenter, dog således at kerner kun kan adjungeres til andre kerner, og fraser kun kan adjungeres til andre fraser. X-bar-konstituenter (intermediære projektioner) kan ikke adjungeres.

Adjunktion ser ud som følger, hvor den adjungerede konstituent, $\mathrm{ZP} / \mathrm{Z}^{\circ}$, kan adjungeres enten til højre (som vist) eller til venstre for den $\mathrm{XP} / \mathrm{X}^{\circ}$ som den modificerer:

a.

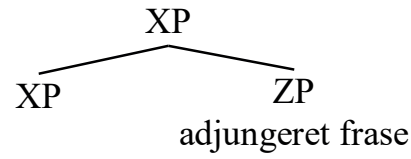

b.

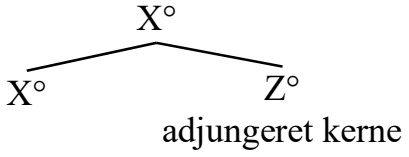

I (7) ser vi et eksempel på adjunktion, idet PP'en $i$ Lystrup er højreadjungeret til VP'en kobe en brugt bil (dvs. $i$ Lystrup svarer til ZP og kabe en brugt bil svarer til den nederste XP i (6)a). (7)a indeholder således to VP'er: En VP der indeholder kabe en brugt bil men ikke $i$ Lystrup, og som kan foranstilles, som vist i (7)b; såvel som en VP der indeholder både kabe en brugt bil og $i$ Lystrup, og som også kan foranstilles, som vist i (7)c:

\section{(7)}

a. Thomas ville aldrig [ ${ }_{\mathrm{VP}}$ VVP $_{\mathrm{p}}$ købe en brugt bil] i Lystrup].

b. [ [vp Købe en brugt bil] ville Thomas aldrig gøre i Lystrup.

c. [ $\quad[\mathrm{VP}$ Købe en brugt bil i Lystrup] ville Thomas aldrig gøre. 
I den noget forenklede generative analyse anvendt her er strukturen den samme for både hovedsætninger og bisætninger (jf. (1)a og (2)a ovenfor og afsnit 3.1 nedenfor), nemlig:

En sætning

komplementet til dens

komplementet til dennes

$$
\begin{array}{ll} 
& \text { er en } \mathbf{C P}, \\
\text { kerne }\left(=\mathrm{C}^{\circ}\right) & \text { er en } \mathbf{I P}, \\
\text { kerne }\left(=\mathrm{I}^{\circ}\right) & \text { er } \quad \text { en } \mathbf{V P} .^{8}
\end{array}
$$

Det at en kerne $\left(\mathrm{fx}^{\circ}\right.$ eller $\left.\mathrm{V}^{\circ}\right)$ i den generative analyse kan være søster til en maksimal projektion (fx VP eller DP), se (1)a og (2)a, er en klar forskel fra sætningsskemaerne hvor et felt kun kan være søster til et andet felt, og en plads kun kan være søster til en anden plads, se (1)b og (2)b.

\section{FIRE FORSKELLE MELLEM DE TO TILGANGE}

I dette afsnit vil vi behandle fire forskelle mellem Diderichsens sætningsskemaer og den generative analyse og prøve at vurdere hvilken teori der har den største relevans for arbejdet med syntaks.

\subsection{Antallet af pladser}

Den generative analyse i (1)a indeholder to pladser mere end Diderichsen-analyserne i (1)b-c: VP-spec (søsteren til V') og $I^{\circ}$. (1) gentages i (9) $\mathrm{i}$ lidt forenklet form.

8 Som det vil fremgå af (35), er de tre kategorier CP, IP og VP direkte oversættelige til begreber der også er relevante for den funktionelle lingvistik. 
(9)

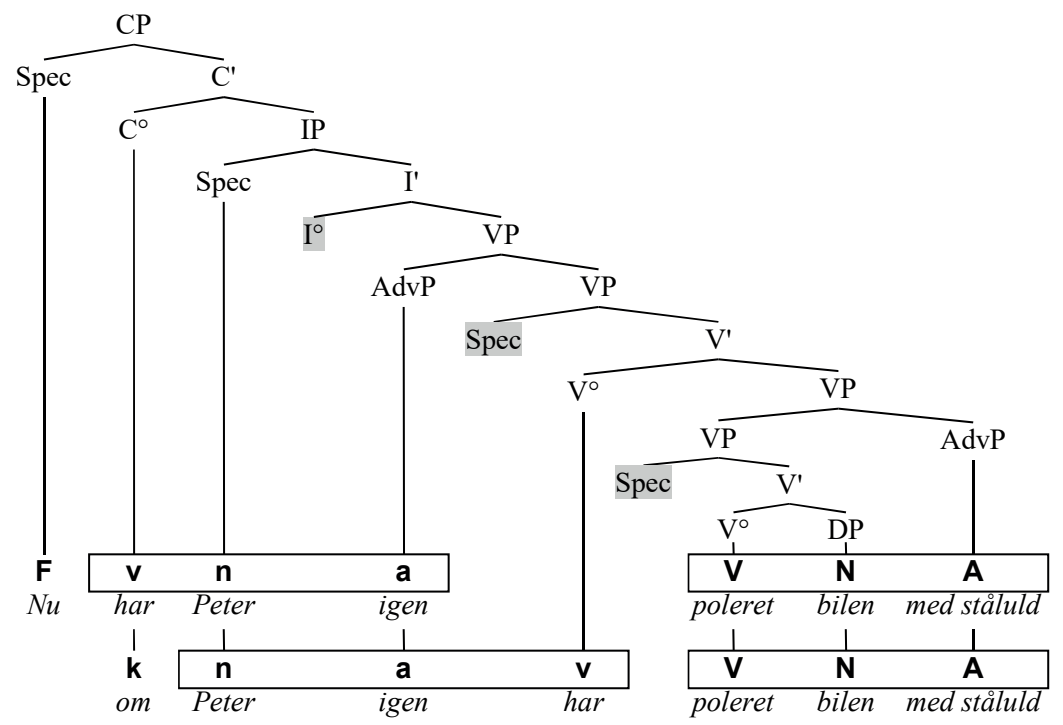

VP-spec antages at være subjektets basisposition, selvom subjektet altid flytter til IP-spec (se fx McCloskey 1997).

$\mathbf{I}^{\circ}$ modsvarer aldrig en selvstændig konstituent på dansk (og på engelsk udfyldes den kun af finitte hjælpeverber og det finitte hovedverbum be), hvorimod $\mathrm{I}^{\circ}$ på islandsk og på fransk kan indeholde alle typer af finitte verber (se fx Vikner 1995: 137-140, 1999, hvor det foreslås at det kun er på sprog med en righoldig verbalfleksion at $\mathrm{I}^{\circ} \mathrm{kan}$ indeholde det finitte verbum).

Den generative analyse kan således bruges til at sige noget principielt om forskellene mellem forskellige sprog, ${ }^{9}$ hvorimod forskellige sprog simpelthen har brug for forskellige analyser set fra et Diderichsen-synspunkt - to strukturer (sætningsskemaer) for dansk, norsk og svensk, se (1)b-c/(9), to andre for gammeldansk og islandsk, se Diderichsen (1941: 89), og en helt anden struktur fx for tysk, se (10)b-c nedenfor - uden at analysen giver nogen principiel forklaring på hvorfor

9 I dette tilfælde består det "principielle" i forslaget om at det at have et verbalparadigme med mange forskellige fleksionelle endelser går hånd $\mathrm{i}$ hånd med det at $\mathrm{I}^{\circ} \mathrm{kan}$ indeholde det finitte hovedverbum: Islandsk og fransk har begge dele, dansk og engelsk har ingen af delene. 
dansk ikke følger den islandske struktur, eller hvorfor islandsk ikke følger den danske struktur.

Især det at den generative analyse siger noget principielt om strukturforskellene mellem dansk og islandsk, er vigtigt idet man dermed også kan sige noget om den historiske udvikling af dansk, i dette tilfælde noget om hvordan dansk før så ud (som islandsk), hvordan det nu ser ud (som i (1)/(9)), og hvorfor der er sket en ændring. ${ }^{10}$

For flere detaljer og referencer angående feltanalysen af tysk, (10) b-c, se Wöllstein-Leisten et al. (1997: 53-75) eller en nyere udgave af Duden-grammatikken (fx Eisenberg et al. 2006: 879).

(10) a.

b.

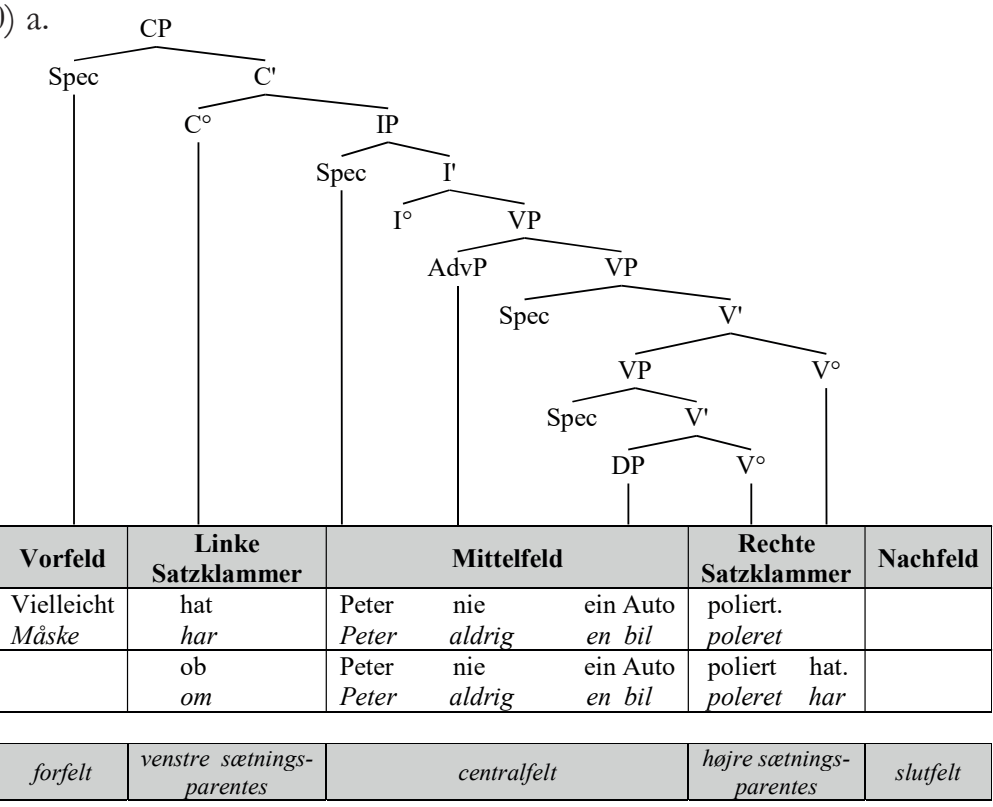

På den anden side har Diderichsens analyse(r) af dansk og også den tilsvarende af tysk i (10)b-c (i modsætning til den generative analyse) den umiddelbare fordel at de ikke opererer med nogen pladser som aldrig kan findes udfyldt.

10 Ændringen af placeringen af det finitte hovedverbum i danske bisætninger (dvs. fra $\mathrm{I}^{\circ}$ til $\mathrm{V}^{\circ}$ ) kan dermed forbindes med forenklingen af det verbale fleksionssystem (se fx Vikner 1999) 


\subsection{Antallet af konstituenter}

Der er som nævnt flere konstituenter/bestanddele/underinddelinger i den generative analyse, (1)a, end der er i Diderichsen (1946), (1)b-c. Færre eller flere konstituenter er selvfølgelig ikke godt eller dårligt i sig selv. Det centrale er for det første at alle de konstituenter som man kan påvise eksistensen af, også repræsenteres som konstituenter i analysen, og for det andet at de forskellige konstituenter ikke strider mod hinanden.

Her skal det understreges at også Diderichsen (1946) er interesseret $i$ konstituentstruktur, fx det at kunne teste om en række af ord udgør en konstituent eller ej. Dette fremgår tydeligt af Diderichsen (1946: 163, 166), hvor det der dér kaldes "fundamentprøven" (dvs. om en række af ord kan flytte til fundamentfeltet/CP-spec), bruges til at vise at bjem til Ribe udgør en konstituent i Han rejste ikke hjem til Ribe, hvorimod bjem $i$ går ikke udgør en konstituent i Han rejste ikke hjem i går.

Vi vil her anvende to slags argumenter for at betragte en række af ord som en konstituent: Den ovennævnte flytning til fundamentfeltet/ CP-spec og substitution med et pronomen (her med efterfølgende flytning til fundamentfeltet/CP-spec). [] afgrænser den pågældende konstituent, og _ _ viser hvor den er flyttet fra. Linjerne over (11) angiver først Diderichsens analyse $\left(\mathbf{V}\right.$...) og dernæst den generative analyse $\left(\mathrm{V}^{\circ}\right.$ ...). Det kan således vises at en VP som inkluderer et slutstillet adverbial, er en konstituent (og den svarer til indholdsfeltet i Diderichsen (1946) forudsat at der kun er ét infinit verbum): ${ }^{11}$

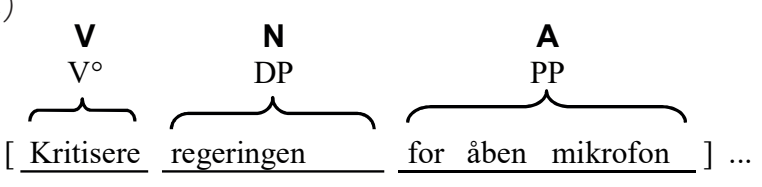

... ville departementschefen under ingen omstændigheder

$(\mathbf{V}+\mathbf{N}+\mathbf{A}=$ indholdsfeltet $)\left(V^{\circ}+\mathrm{DP}+\mathrm{PP}=\mathrm{VP}\right)$

11 Analysen i (11) er parallel til Diderichsens (1946: 166) analyse af Sende bornene bjem turde han ikke. Vi har udskiftet Diderichsens eksempel for at komme uden om de vanskeligheder der opstår efter at hjem $\mathrm{i}$ kraft af at være forbundet med verbet gennem tryktab ikke kan analyseres som et klassisk A-adverbial, se Thomsen (2002), Hansen og Heltoft (2011: 1599-1606), Peter$\operatorname{sen}(2015)$. 
I den generative analyse er et slutstillet adverbial adjungeret til VP, hvilket betyder at der både er en VP der også indeholder det slutstillede adverbial (som det fremgår af (11) og (12) ovenfor), og en VP der ikke indeholder det slutstillede adverbial (som det fremgår af (13) og (14) nedenfor). Sidstnævnte, en VP der ikke omfatter det slutstillede adverbial, udgør ikke en konstituent i Diderichsens (1946) analyse, som derfor ikke umiddelbart forudsiger følgende data:
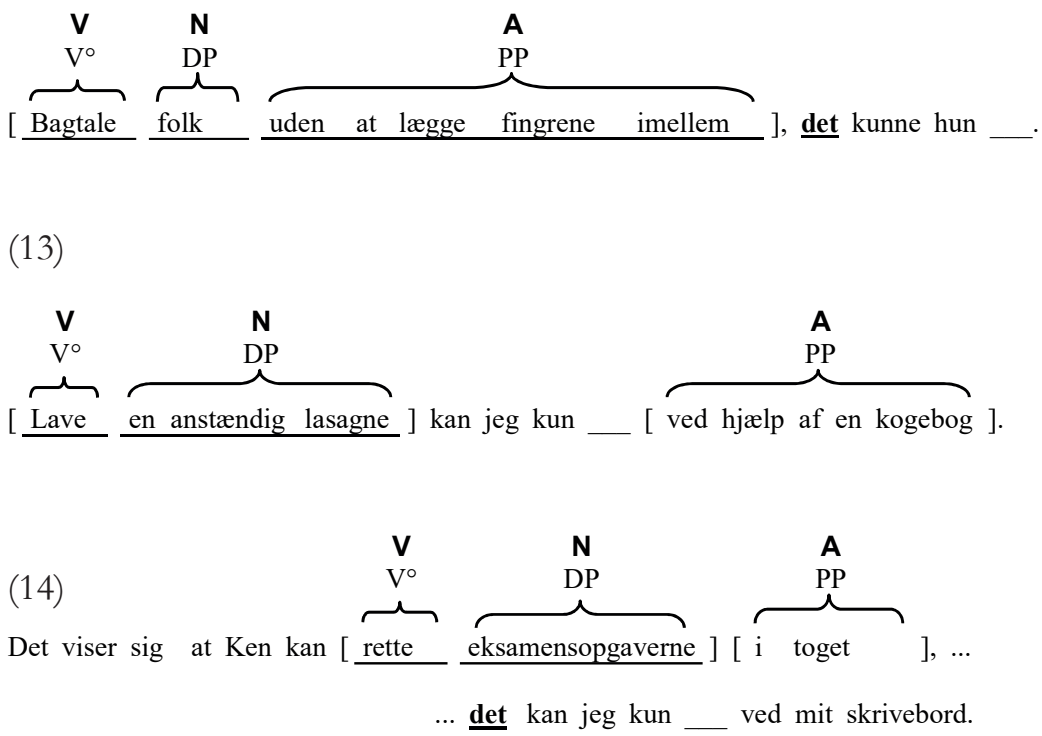

Vi mener altså at (13) og (14) er problematiske for Diderichsens (1946) analyse på følgende måde: På den ene side opdeler analysen sætningen $i$ bestemte bestanddele, inklusive (indholdet af) indholdsfeltet, dvs. rette eksamensopgaverne i toget i (14), og (indholdet af) de tre pladser $\mathbf{V}$, dvs. rette, $\mathbf{N}$, dvs. eksamensopgaverne, og $\mathbf{A}$, dvs. i toget. På den anden side kan det ved hjælp af flytning til fundamentfeltet/CP-spec (den test som også anvendes i Diderichsen 1946: 163) påvises at rette eksamensopgaverne udgør en konstituent, selvom den altså ikke er en af de bestanddele som Diderichsens (1946) analyse deler sætningen op i. 
Lad os gå videre til et andet sæt eksempler, denne gang eksempler med mere end et infinit verbum. Som vist fx i (1)a er der i den generative analyse en VP for hvert verbum, således at en sætning med tre verber også må indeholde tre VP'er, hvor to af dem så har et infinit verbum som kerne. I sådan en sætning vil den række af ord der i den generative analyse udgør den VP der har hovedverbet som kerne, ikke udgøre en konstituent i Diderichsen (1946), idet alle infinitte verber her deler én plads, $\mathbf{V}$.

Det kan imidlertid vises at denne generative VP er en konstituent, idet den kan flyttes til fundamentfeltet/CP-spec, (15) og (18), og den kan substitueres af det, (16) og (19). Der er to forskellige VP'er der er relevante her: Den ene VP, som har hovedverbet som kerne, omfatter kun hovedverbet og dets objekt (VP- $\boldsymbol{\alpha}$ i (17)), og den anden VP, som også har hovedverbet som kerne, omfatter ikke blot hovedverbet og dets objekt men også det slutstillede adverbial (VP- $\beta$ i (17)).

VP- $\alpha$, som kun omfatter hovedverbet og objektet, kan flyttes, (15), og substitueres af det, (16), hvilket efter vores mening udgør et problem for Diderichsens (1946) analyse: På den ene side opdeler denne analyse sætningen i bestemte bestanddele, inklusive (indholdet af) pladsen $\mathbf{V}$, dvs. kunnet lave i (15). På den anden side kan det ved hjælp af flytning til fundamentfeltet/CP-spec påvises at lave en anstandig lasagne udgør en konstituent (den vi kalder VP- $\alpha$ ), selvom denne altså strider mod de bestanddele (pladser) som Diderichsens (1946) analyse deler sætningen op i.
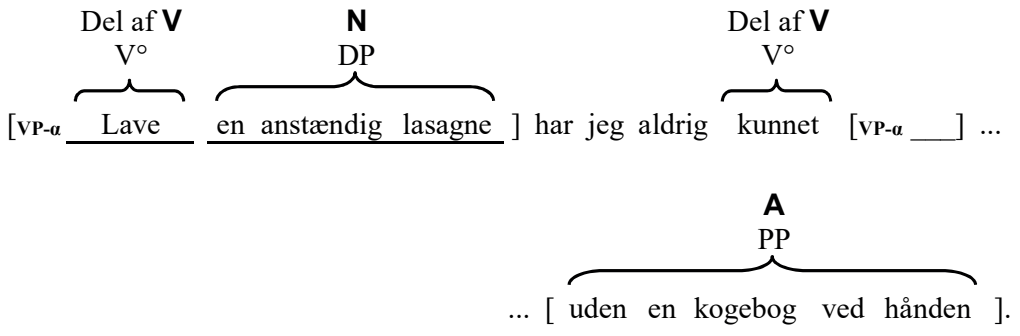
(16)
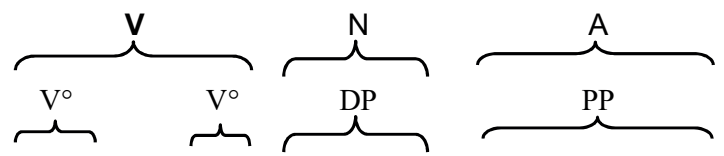

Maria sagde at Egon skulle [vp- åbne pengeskabet ] med en papirkniv , ... ... men det sagde han at han kun kunne [VP- $\alpha \_$__ med rigtigt værktøj.

(17)

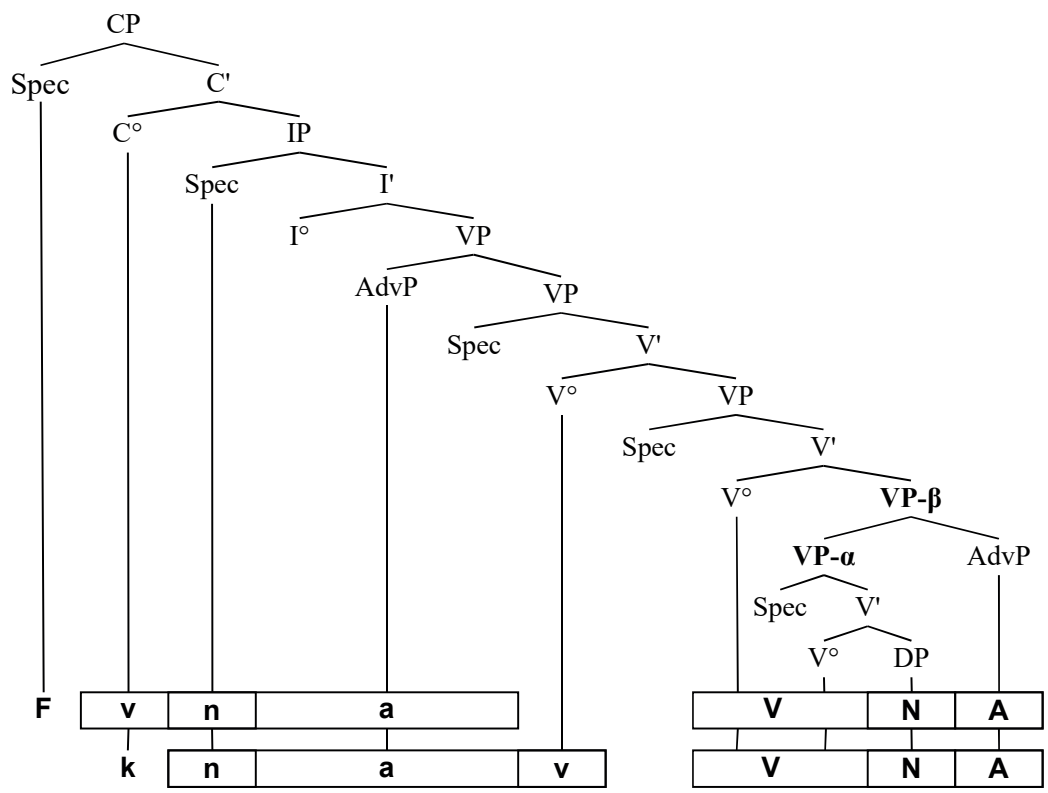

Også VP- $\beta$ (hovedverbum, objekt og slutstillet adverbial), kan både flyttes, (18), og substitueres af det, (18) og (19): 

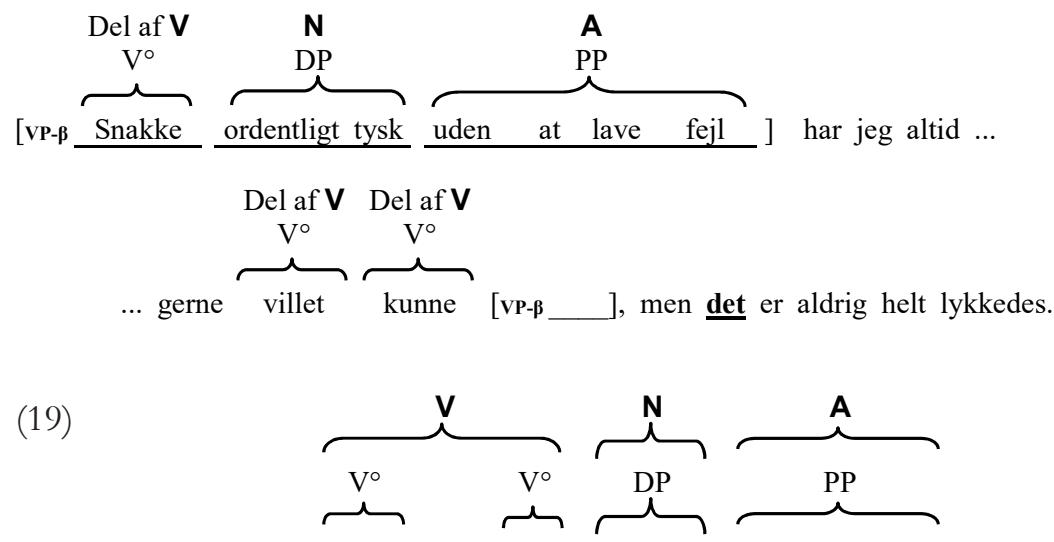

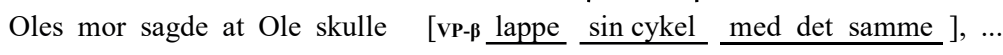

... og det synes jeg også at du skulle [vP- $\beta \ldots$

Som i (15)-(16) er de understregede rækker af ord i (18)-(19) klare tilfælde af modstridende grænser for bestanddele/konstituenter: På den ene side har Diderichsens (1946) analyse en bestanddel af sætningen som er pladsen $\mathbf{V}$, som i (18) udgøres af villet kunne snakke. På den anden side kan det påvises ved hjælp af flytning til fundamentfeltet/CPspec, som Diderichsen $(1946: 166,192)$ i øvrigt selv observerer, at der er en bestanddel, nemlig den vi her kalder VP- $\beta$, som i (18) udgøres af snakke ordentlig tysk uden at lave fejl. Det at verbalformen snakeke således i en Diderichsen-analyse må opfattes som en del af to forskellige bestanddele af sætningen, burde efter vores mening være ligeså umuligt som at en bestemt person befinder sig $i$ to forskellige byer samtidig.

Selvom danske sætninger således opdeles i langt flere bestanddele i den generative analyse, (1)a, end i Diderichsens (1946) analyse, (1)b-c, er dette en fordel og ikke en ulempe, fordi det medfører at den generative analyses opdeling er kompatibel med langt flere af de konstituenter hvis eksistens kan påvises, end Diderichsens (1946) analyse er.

Helt parallelle argumenter bliver ofte fremført i forbindelse med den tyske feltanalyse, (10)b-c: Der findes nemlig konstituenter (også i (20) 
drejer det sig om en VP, sein eigenes Auto polieren) som består af en del af et felt og en del af et andet felt.

\begin{tabular}{|l|c|c|c|c|}
\hline \multicolumn{1}{|c|}{ Vorfeld } & $\begin{array}{c}\text { Linke } \\
\text { Satz- } \\
\text { klammer }\end{array}$ & Mittelfeld & $\begin{array}{c}\text { Rechte } \\
\text { Satzklammer }\end{array}$ & Nachfeld \\
\hline $\begin{array}{l}\text { Sein eige- } \\
\text { nes Auto } \\
\text { polieren }\end{array}$ & wird & $\begin{array}{l}\text { Peter wohl nie } \\
\text { Peter vel aldrig }\end{array}$ & müssen. & \\
Sin egen & & & & \\
bil polere & & & & \\
\hline
\end{tabular}

På den ene side må det indrømmes at begge analyser indfører konstituenter som ikke umiddelbart ser ud til at kunne påvises ved hjæp af konstituenttests ( $f x C^{\prime}$ i den generative analyse eller neksusfeltet $i$ Diderichsen 1946). På den anden side har vi ovenfor søgt at vise at de to analyser ikke står lige med hensyn til at kunne redegøre for de konstituenter som kan påvises ved hjæp af konstituenttests: Adskillige af de konstituenter hvis eksistens kan påvises, går på tværs af den opdeling af dansk sætningsstruktur som foretages i Diderichsens (1946) analyse. Derimod er der ingen konflikter mellem de konstituenter hvis eksistens kan påvises, og den opdeling af dansk sætningsstruktur som foretages $i$ den generative analyse.

\subsection{Asymmetri: C-kommando og pronominal koreference}

Som nævnt i indledningen er både Diderichsen-sætningsskemaerne $\mathrm{i}$ (1)b og Diderichsen-træstrukturen i (2)b langt fladere end de tilsvarende generative træstrukturer og feltstrukturer i (1)a og (2)a. Grunden er bl.a. at den generative analyse ikke tillader mere end bincer forgrening (binary branching), dvs. hver knude i træstrukturen eller hvert felt i feltstrukturen må højst deles op i to knuder/felter på niveauet nedenunder. En af konsekvenserne er at der er mere asymmetri i den generative analyse: Det er meget få konstituenter der er på samme niveau, og det er det 
der udnyttes i definitionen af den relation der kaldes C-kommando, som er en vigtig bestanddel af mange forskellige generaliseringer angående fx negative polaritetselementer (Vikner 2013), refleksive pronominer (Vikner 1985), og det der skal vises her, pronominal koreference.

Hvis man betragter en forskel som (21)a,b, hvor de understregede konstituenter skal betragtes som koreferentielle, kunne det se ud som om det der er i vejen med (21)a, er at et pronomen, de, ikke må gå forud for den DP, Anna og Bo, som pronominet er koreferent med.

(21) a. * Jeg tror ikke at $\underline{\text { de }}$ vidste at Anna og Bo var blevet fotograferet.

b. Jeg tror ikke at Anna og Bo vidste at de var blevet fotograferet.

At dette ikke er en tilfredstillende regel fremgår af (22)a,b, hvor de kan både gå forud for og følge efter Anna og Bo:

(22) a. Uden at de vidste det, var Anna og Bo blevet fotograferet

b. Uden at Anna og Bo vidste det, var de blevet fotograferet

Vi har altså brug for et andet bud på noget der bliver overtrådt i (21)a, og det skal være noget der hverken bliver overtrådt i (21)b eller i (22) a,b. Dermed kan det ikke være en præcedens-relation, der jo bliver overtrådt ikke alene i (21)a men også i (22)a.

I stedet vil vi argumentere for at den relevante relation mellem en ikke-pronominal nominalgruppe og et pronomen er mere kompliceret, som i (23):

En ikke-pronominal DP må ikke være en del af søsterkonstituenten til et koreferentielt pronomen.

Denne relation (at være en del af søsterkonstituenten til noget) er det den generative lingvistik kalder C-kommando:

\begin{tabular}{|c|c|}
\hline C-kommando: & $\begin{array}{l}\text { X c-kommanderer Y hvis og kun hvis } \\
\text { a. alle konstituenter der indeholder X, også indeholder Y, } \\
\text { b. hverken X eller Y indeholder den anden. }\end{array}$ \\
\hline
\end{tabular}


Denne definition kan også formuleres på andre måder, og her er to alternativer:

- Hvis Y er en del af søsterkonstituenten til X, så vil X c-kommandere $\mathrm{Y}$, ELLER

- Hvis man kan komme fra X til Y i træet ved at klatre et trin op og derefter klatre nedad resten af vejen, så vil X c-kommandere Y.

Reglen om koreference i (23) svarer nu helt til

En ikke-pronominal DP må ikke c-kommanderes af et koreferentielt pronomen.

(= princip C i Chomskys bindingsteori, Chomsky 1981: 188.)

I (26), som er strukturen for (21)a, c-kommanderer de således Anna og $B o$, idet Anna og Bo er en del af søsterkonstituenten til de. Det vil sige at (26) viser hvorledes (21)a overtræder koreferencereglen i (23)/(25), hvilket igen korrekt forudsiger at det ikke er muligt at have koreference mellem de og Anna og Bo i (21)a.

Hvis derimod man bytter om på de og Anna og Bo i (26), så bliver koreferencereglen i (23)/ (25) ikke overtrådt, hvilket igen korrekt forudsiger at det er muligt at have koreference mellem de og Anna og Bo i (21)b. 
(26) *Jeg tror ikke...

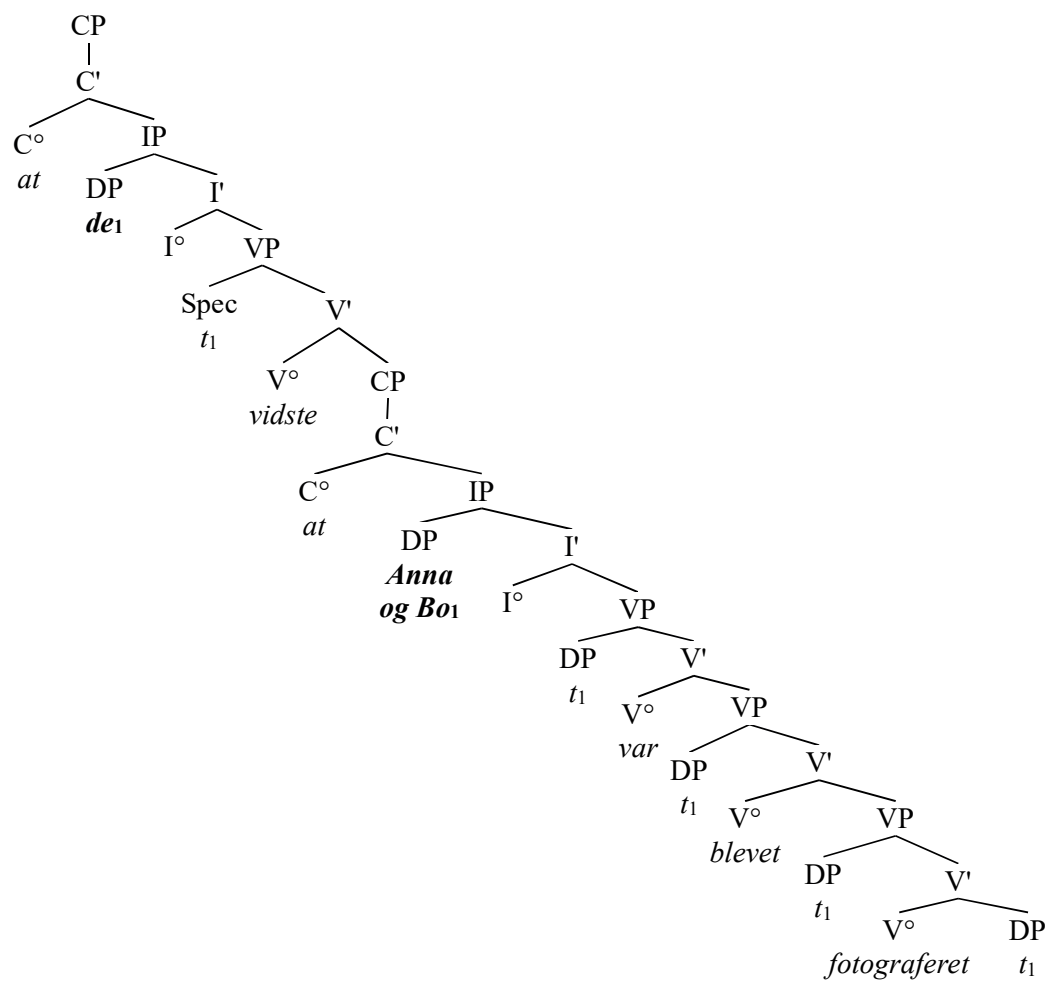

Hvis vi nu ser på (27), som er strukturen for (22)a, så kan vi se at selvom de går forud for Anna og Bo, så bliver Anna og Bo ikke c-kommandereret af $d e$, idet Anna og Bo ikke er en del af søsterkonstituenten til $d e$. Det vil sige at (27) viser at (22)a ikke overtræder koreferencereglen i (23)/(25), hvilket igen korrekt forudsiger at det er muligt at have koreference mellem de og Anna og Bo i (22)a.

Hertil kommer at selvom man bytter om på de og Anna og Bo i (27), så bliver koreferencereglen i (23)/(25) stadig ikke overtrådt, hvilket igen korrekt forudsiger at det også er muligt at have koreference mellem de og Anna og Bo i (22)b. 


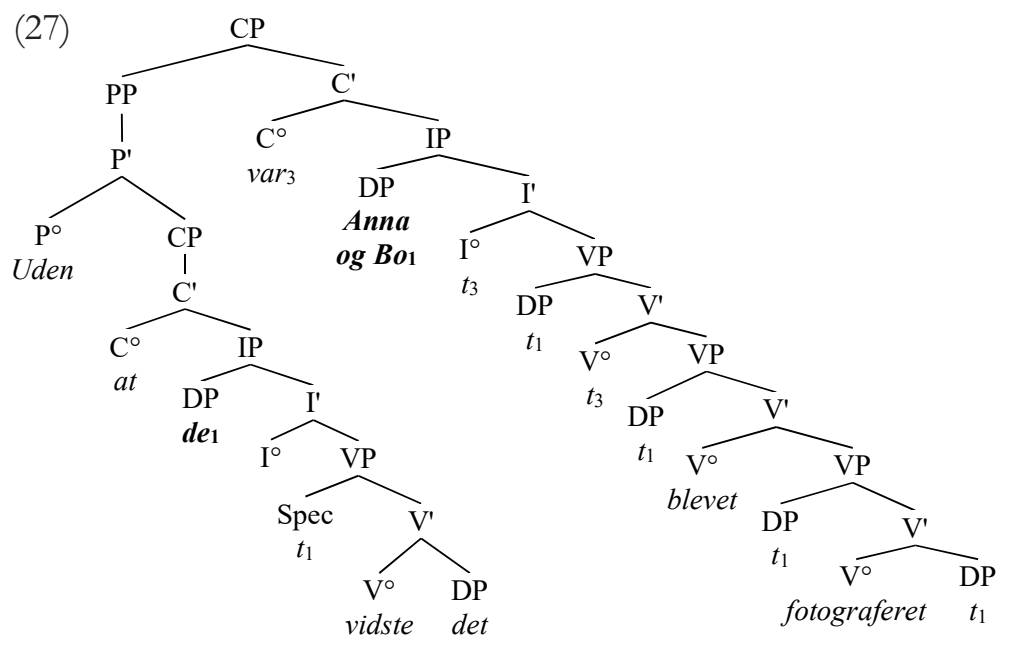

Denne type analyse forudsætter en grundlæggende asymmetri mellem fx subjekt og objekt, hvilket som sagt er tilfældet i de generative strukturer i (1)a og (2)a, men ikke i Diderichsens sætningsskemaer i (1)b og (2)b.

\subsection{To satningsskemaer vs. én generativ struktur}

Diderichsen (1946) selv relaterer ikke hovedsætningsskemaet og bisætningsskemaet direkte til hinanden, hvilket man inden for Diderichsentraditionen har søgt at råde bod på sidenhen. Det første egentlige forsøg på at etablere hvilke pladser i det ene skema der svarer til hvilke pladser i det andet skema, er Hansen (1977: 73), se (32) nedenfor. Den kobling af de to skemaer som vi (og fx Heltoft 1986: 108 og Hansen \& Heltoft 2011: 328-330) foretrækker, kommer oprindelig fra Platzack (1985: 71, fodnote 5), se (34) nedenfor.

De forskellige forsøg på at koble de to sætningsskemaer direkte til hinanden kan deles op $i$ tre grupper, hvis man deler dem op efter hvorledes de behandler forskellene mellem neksusfeltet i hovedsætningsskemaet og det i bisætningsskemaet. (De pladser/felter i hovedsætningerne i (28)-(34) der afviger fra bisætningerne, er farvet grå.)

I den første gruppe er alle pladser i neksusfeltet i hovedsætningen forskellige fra bisætningen: 
(28) Allan et al.

(1995: 498)

\begin{tabular}{|l|l|l|l|l|l|l|l|l|}
\hline $\mathbf{k}$ & $\mathbf{n}$ & $\mathbf{a}$ & & $\mathbf{v}$ & $\mathbf{V}$ & $\mathbf{N}$ & $\mathbf{A}$ & bisætning \\
\hline $\mathbf{k}$ & $\mathbf{F}$ & $\mathbf{v}$ & $\mathbf{n}$ & $\mathbf{a}$ & $\mathbf{V}$ & $\mathbf{N}$ & $\mathbf{A}$ & hovedsætning \\
\hline
\end{tabular}

Her svarer $\mathbf{v}$ i hovedsætningen til $\mathbf{a} \mathrm{i}$ bisætningen, og $\mathbf{a}$ i hovedsætningen svarer til $\mathbf{V}$ i bisætningen. Udover at $\mathbf{V}$ og $\mathbf{a}$ bytter plads, svarer subjektspositionen $\mathbf{n}$ i hovedsætningen til fundamentfeltet $\mathrm{i}$ bisætningen.

(29) Lundskær-

Nielsen et al.

(2010: 584) ${ }^{12}$

\begin{tabular}{|l|l|l|l|l|l|l|l|l|}
\hline $\mathbf{k}$ & & $\mathbf{n}$ & $\mathbf{a}$ & $\mathbf{v}$ & $\mathbf{V}$ & $\mathbf{N}$ & $\mathbf{A}$ & bisætning \\
\cline { 1 - 4 } $\mathbf{k}$ & $\mathbf{F}$ & $\mathbf{v}$ & $\mathbf{n}$ & $\mathbf{a}$ & $\mathbf{V}$ & $\mathbf{N}$ & $\mathbf{A}$ & hovedsætning \\
\hline
\end{tabular}

Her er der en total ombytning af de tre pladser i neksusfeltet: $\mathbf{v}-\mathbf{n}-\mathbf{a}$ i hovedsætningen bliver til $\mathbf{n}-\mathbf{a}-\mathbf{v}$ i bisætningen.

I den anden gruppe svarer $\mathbf{V}$-pladsen i hovedsætningen til $\mathbf{V}$-pladsen $\mathrm{i}$ bisætningen:

(30) Becker-

Christensen

(2010: 82)

\begin{tabular}{|l|l|l|l|l|l|l|l|l|}
\hline $\mathbf{k}$ & $\mathbf{n}$ & $\mathbf{a}$ & $\mathbf{v}$ & & $\mathbf{V}$ & $\mathbf{N}$ & $\mathbf{A}$ & bisætning \\
\hline & $\mathbf{F}$ & & $\mathbf{v}$ & $\mathbf{n}+\mathbf{a}$ & $\mathbf{V}$ & $\mathbf{N}$ & $\mathbf{A}$ & hovedsætning \\
\hline
\end{tabular}

Prisen for at holde $\mathbf{v}$ konstant i hovedsætningen og i bisætningen er at både $\mathbf{n}$ og $\mathbf{a}$ så skal være på forskellige pladser. Hertil kommer den asymmetri at $\mathbf{n}$ og $\mathbf{a}$ er på to forskellige pladser i bisætningen, mens de deler en plads i hovedsætningen.

I den tredje gruppe er både $\mathbf{n}$ - og $\mathbf{a}$-pladserne de samme i hovedog bisætningen:

(31) Togeby

(2003: 98-

102)

\begin{tabular}{|l|l|l|l|l|l|l|l|l|l|l|}
\hline & & & $\mathbf{k}$ & $\mathbf{n}$ & $\mathbf{a}$ & $\mathbf{V}$ & $\mathbf{V}$ & $\mathbf{N}$ & $\mathbf{A}$ & bisætning \\
\hline $\mathbf{k}$ & $\mathbf{F}$ & $\mathbf{v}$ & & $\mathbf{n}$ & $\mathbf{a}$ & & $\mathbf{V}$ & $\mathbf{N}$ & $\mathbf{A}$ & hovedsætning \\
\hline
\end{tabular}

(32) Hansen

(1977: 73)

\begin{tabular}{|l|l|l|l|l|l|l|l|l|l|l|}
\hline $\mathbf{k}$ & $\mathbf{k}$ & & & $\mathbf{n}$ & $\mathbf{a}$ & $\mathbf{v}$ & $\mathbf{V}$ & $\mathbf{N}$ & $\mathbf{A}$ & bisætning \\
\hline $\mathbf{k}$ & & $\mathbf{F}$ & $\mathbf{v}$ & $\mathbf{n}$ & $\mathbf{a}$ & & $\mathbf{V}$ & $\mathbf{N}$ & $\mathbf{A}$ & hovedsætning \\
\hline
\end{tabular}

12 Lundskær-Nielsen et al. (2010) er den reviderede udgave af Allan et al. (1995). 
I (31) og (32) svarer $\mathbf{v}$ (det finitte verbum) i hovedsætningen ikke til $\mathbf{k}$ (den underordnende konjunktion) i bisætningen, selv om alle 12 eksempler der illustrerer det "totale" sætningsskema i Togeby (2003: 102) enten har $\mathbf{V}$ tom og $\mathbf{k}$ udfyldt, eller $\mathbf{V}$ udfyldt og $\mathbf{k}$ tom (se også Vikner 2007: 471-474).

I de sidste to analyser i den tredje gruppe, (33) og (34), svarer $\mathbf{V}$ (det finitte verbum) i hovedsætningen til $\mathbf{k}$ (den underordnende konjunktion) $i$ bisætningen. Forskellen er at i Jørgensen (2000: 70) er der en plads (k) i bisætningen der svarer til to pladser $(\mathbf{F}$ og $\mathbf{V})$ i hovedsætningen:

Jørgensen (2000: 70)

\begin{tabular}{|c|c|c|c|c|c|c|c|c|}
\hline \multicolumn{2}{|c|}{ k } & $\mathbf{n}$ & $\mathbf{a}$ & $\mathbf{v}$ & $\mathbf{V}$ & $\mathbf{N}$ & A & \\
\hline $\mathbf{F}$ & $\mathbf{v}$ & $\mathbf{n}$ & a & & V & $\mathbf{N}$ & A & hovedsætning \\
\hline
\end{tabular}

(34) Platzack (1985: 71, fn 5), Heltoft (1986: 108), Hansen \&

\begin{tabular}{|c|c|c|c|c|c|c|c|c|}
\hline $\mathbf{( F )}$ & $\mathbf{k}$ & $\mathbf{n}$ & $\mathbf{a}$ & $\mathbf{v}$ & $\mathbf{V}$ & $\mathbf{N}$ & $\mathbf{A}$ & bisætning \\
\hline $\mathbf{F}$ & $\mathbf{v}$ & $\mathbf{n}$ & $\mathbf{a}$ & & $\mathbf{V}$ & $\mathbf{N}$ & $\mathbf{A}$ & hovedsætning \\
\hline
\end{tabular}
Heltoft (2011: 328-330)

Det at man inden for både den generative forskning og den Diderichsen-basererede forskning har forsøgt at aflede hovedsætningsanalysen og bisætningsanalysen fra en og samme analyse, viser at det ikke nødvendigvis er centralt at Diderichsen (1946) har to sætningsskemaer der er uafhængige af hinanden. Dermed er denne forskel mellem de to tilgange formentlig heller ikke særlig central, i modsætning til de forskelle vi behandlede i afsnit 2.1, 2.2 og 2.3.

\section{TRE PARALLELLER MELLEM DE TO TILGANGE}

3.1 De tre overordnede felter $i$ Diderichsen (1946) og hvad de svarer til Det første eksempel på konvergens mellem de to analyser vedrører de tre overordnede felter i Diderichsen (1946) og hvad de svarer til i den generative analyse. De centrale konstituenter på sætningsniveauet i den generative analyse, dvs. CP, IP og VP, kan nemlig ses som parallelle med de domæner der ofte antages i de funktionelle analyser der byg- 
ger på Diderichsen (1946), se fx Togeby (2003: 9, 327n), Harder (2005: 106) og Hansen \& Heltoft (2011: 145-8).

(35), som er fra Christensen (2005: 30), viser at en parallel lagdelt struktur også findes i den generative analyse, se også fx Platzack (2010: 84) og van Gelderen (2014: 65).

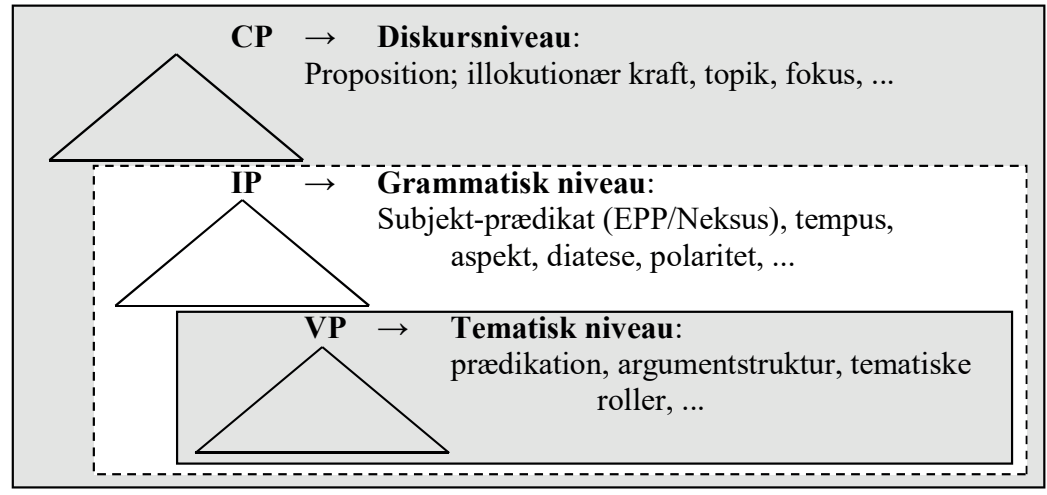

Ved første øjekast kunne denne konvergens mellem funktionel grammatik og generativ syntaks se ud til ikke at inkludere Diderichsen (1946): Hvor hvert niveau i (35) indeholder det næste niveau nedenunder, er felterne i Diderichsen (1946) separate konstituenter der ikke omfatter hinanden, jf. fx (1)b ovenfor og Diderichsen (1946: 161-162). Dette er dog formentlig ikke et problem, af de to følgende grunde.

En grund er at nogle af de analyser der bygger på Diderichsen (1946), antager at i hvert fald nogle af felterne er dele af andre felter. I Hansen \& Heltoft (2011: 329) er fx indholdsfeltet en del af kernefeltet. Noget tilsvarende gør sig gældende hos Togeby (2003: 268) og Blom (2006: 43), og faktisk også hos Diderichsen (1946: 186), hvor parentesstrukturen ovenfor tabellen ser ud som følger:

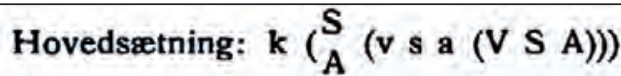


Den anden grund er at selv om Diderichsens felter ikke omfatter andre felter, så er generaliseringerne parallelle $\mathrm{i}$ alle tre tilgange: Den generative opfattelse af hvad der sker på IP-niveauet (som også omfatter VP'en, (35)) er helt parallel til Diderichsens opfattelse af hvad der sker i neksusfeltet, også selv om indholdsfeltet ikke er en del af neksusfeltet, se (1)b-c:

(37)

\begin{tabular}{|l|l|}
\hline Fundamentfeltet & $\begin{array}{l}\text { Orientering mod sætningens kontekst, diskursrelevante elemen- } \\
\text { ter }\end{array}$ \\
\hline Neksusfeltet & Snitflade mellem kommunikation og indhold,fx polaritet, aspekt \\
\hline Indholdsfeltet & Organisering af indholdet: aktanter, frie led \\
\hline
\end{tabular}

(baseret på Diderichsen 1941: 35; Togeby 2003: 50-51; Harder 2005)

Dette skyldes at Diderichsens (1946) neksusfelt omfatter de elementer i den generative analyse som er del af IP men ikke af VP.

\subsection{Topologi vs. syntaks}

Den generative analyse kunne måske se ud til ikke at indeholde en distinktion der svarer til Diderichsens to niveauer "topologi" og "syntaks", som Heltoft (1986: 121) beskriver som følger: "topologisk analyse (Hvor står hvilke konstituenter?) og syntaktisk analyse (Hvilke konstituenter kan en sætning bestå af og hvordan kan de kombineres?)".

I den generative analyse vil både den "topologiske analyse" og den "syntaktiske analyse" være en del af syntaksen. Ikke desto mindre kan man foretage parallelle distinktioner ved hjælp af flytningsmekanismen. En flyttet konstituent efterlader et spor (og flere end et hvis det flytter i flere skridt). Et eksempel som (38) bliver således analyseret som i (39):

(38) Da. Den her bog kendte Jakob ikke 


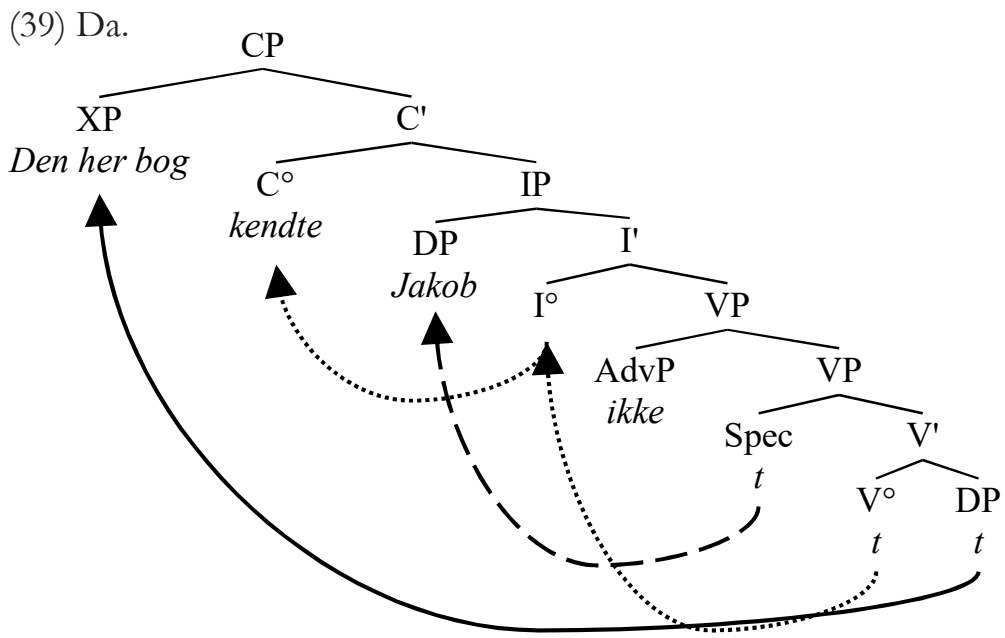

Den her bog er i CP-spec (Diderichsens topologi: Det står i fundamentfeltet, $\mathbf{F}$ ), og det har efterladt et spor på komplementspladsen til kendte (Diderichsens syntaks: Det er objektet for kendte).

Man kan derfor sige at Diderichsens distinktion mellem "topologi" og "syntaks" svarer til forskellen mellem udgangspositionen og landingspositionen i den generative analyse.

\subsection{Fytninger og spor}

Som vist i (39) kan konstituenter flytte rundt i sætningen i den generative analyse. Det er værd at understrege at det samme er tilfældet $i$ Diderichsen (1946), som det fremgår af følgende diskussion af præpositionsstranding og "pied piping" i Diderichsen (1946: 228):

Man kan lægge Genstanden selv til Grund for Udsagnet (som "Genstandsfundament"), og Konjunktionalet bliver da adskilt fra Ledstammen og henstaar paa sin Plads i Indholdsfeltet: Mig tankte du vel ikke paa? | Hans sidste Digte er der ikke meget ved. Eller man kan gaa ud fra en Situation og flytter da Konjunktionalet med: I den lille By var der stort Rore.

Hansen (1977: 55) nævner "opflytning til fundamentfeltet" og giver eksempler (1977: 61, 75) med flyttede konstituenter hvor den "normale placering" er vist med "()", svarende til et spor i den generative analyse: 
(41) Da. a. Vinden fører () med sig langt ud over havet en duft af hø og nyslåede enge.

b. Den bemærkning lod jeg bare som om jeg ikke havde hørt ().

Lundskær-Nielsen et al. (2010: 597, 601) nævner også flytninger indenfor sætningen, og Jørgensen (2000: 69) bruger betegnelsen "fremrykning" både til fundamentfeltet og af det finitte verbum i hovedsætninger.

\section{KONKLUSION}

Vores mål med denne artikel ${ }^{13}$ var at illustrere både hvor meget den generative analyse og Diderichsen (1946) har til fælles, og hvad præcist der skiller dem ad:

\begin{tabular}{|l|l|}
\hline tre forskelle: & $\begin{array}{l}\text { antallet af pladser (2.1), antallet af konstituenter (2.2), } \\
\text { asymmetri (2.3), }\end{array}$ \\
\hline en pseudo-forskel: & de to sætningsskemaer vs. én generativ struktur (2.4), \\
\hline tre paralleller: & $\begin{array}{l}\text { de overordnede felter/CP-IP-VP (3.1), topologi og syntaks } \\
\text { (3.2), og syntaktiske flytninger (3.3). }\end{array}$ \\
\hline
\end{tabular}

Mere overordnet er det tydeligt at den generative analyse ikke er skræddersyet til dansk i modsætning til Diderichsen (1946), og derfor har den generative analyse brug for mere "maskineri". Til gengæld har den generative analyse dermed noget principielt at sige om forskellene mel-

13 Tak til Tavs Bjerre, Ken Ramshøj Christensen, Eva Engels, Inger Schoonderbeek Hansen, Lars Heltoft, Torben Juel Jensen, Johannes Kizach, Stephan Müller, Jan Heegård Petersen, Ole Togeby, Carl Vikner, Johanna Wood, Bjarne Ørsnes og en anonym fagfællebedømmer, og til publikum ved Third international workshop on Germanic languages, Freie Universität Berlin, marts 2012, ved Workshop on the Similarities and Differences between Clauses and Nominals, Aarhus, december 2012, ved MUDS 15, Aarhus, oktober 2014, og ikke mindst til de studerende i vores kurser om dansk, engelsk og komparativ syntaks. Denne forskning var en del af to forskningsprojekter ved Aarhus Universitet, finansieret af Forskningsrådet for Kultur og Kommunikation: Objektspositioner - komparativ syntaks $i$ et tvarteoretisk perspektiv og Ligheder og forskelle mellem satninger og nominalgrupper - sammenlignende syntaks på tvars af teoretiske tilgange. 
lem sprog. Hertil kommer at adskillige af de konstituenter hvis eksistens kan påvises, som sagt strider mod den opdeling af dansk sætningsstruktur som foretages i Diderichsens (1946) analyse, hvorimod der ikke er nogen konflikter mellem de konstituenter hvis eksistens kan påvises, og den opdeling af dansk sætningsstruktur som foretages i den generative analyse.

Det er dog også værd at betone at der er mange paralleller mellem tilgangene.

Konklusionen må være at alle syntaktikere burde være parat til at tage både de generative og de funktionelle tilgange alvorligt. Selvom tonen nogle gange kan være lidt polemisk, har de forskellige tilgange meget til fælles, hvilket også betyder at de kan lære noget af hinandens resultater og erkendelser. Dette betyder bestemt ikke at man skal ignorere forskellene mellem tilgangene. I sidste ende vil de forskellige tilgange aldrig blive (helt) enige, og det er nok også fint nok, for som Popper siger:

Since the method of science is that of critical discussion, it is of great importance that the theories discussed should be tenaciously defended. For only in this way can we learn their real power. And only if criticism meets resistance can we learn the full force of a critical argument. (Popper 1994: 93-94)

Sten Vikner

Institut for Kommunikation og Kultur

Aarhus Universitet

sten.vikner@cc.au.dk

Henrik Jørgensen

Institut for Kommunikation og Kultur

Aarhus Universitet

norhj@cc.au.dk 


\section{LITTERATUR}

Allan, R., P. Holmes \& T. Lundskær-Nielsen. 1995. Danish, a comprehensive grammar. London: Routledge.

Austin, J.L. 1984 [1962]. How to do things with words. Oxford: Oxford University Press

Bache, C. \& N. Davidsen-Nielsen. 1997. Mastering English grammar. Berlin: Mouton de Gruyter. DOI: 10.1515/9783110803181.

Becker-Christensen, C. 2010. Dansk syntaks. København: Samfundslitteratur.

Bjerre, T., E. Engels, H. Jørgensen \& S. Vikner. 2008. Points of convergence between functional and formal approaches to syntactic analysis. Working papers in Scandinavian syntax 82. 131-166. www.hum.au.dk/engelsk/engsv/papers/ bjer08a.pdf. Tilgået 9. december 2016.

Blom, J. 2006. Feltanalyse og topologisk rektion. Speciale, Syddansk Universitet.

Bloomfield, L., 1970 [1933]. Language. London: George Allen and Unwin.

Brandt, P.Aa. 1974. Tegn, satning, subjekt. Grenå: GMT.

Chomsky, N. 1981. Lectures on government and binding. Dordrecht: Foris.

Chomsky, N. 1986. Barriers. Cambridge, Mass.: MIT Press.

Christensen, K.R. 2005. Interfaces: Negation - Syntax - Brain. Ph.d.-afhandling, Aarhus Universitet. www.hum.au.dk/engelsk/engkrc/Papers/krc-phd.pdf. Tilgået 9. december 2016 .

Christensen, T.K. 2007. Hyperparadigmer: en undersogelse af paradigmatiske samspil i danske modussystemer. Ph.d.-afhandling, Roskilde Universitet.

Den Danske Ordbog. 2003-05). København: Det danske Sprog og Litteraturselskab. http: //ordnet.dk/ddo. Tilgået 9. december 2016.

Diderichsen, P. 1936. Prolegomena til en metodisk dansk Syntax. Forbandlinger paa det ottende nordiske Filologmode $i$ Kobenhavn 1935, 41-46.

Diderichsen, P. 1939. Realitet som grammatisk Kategori. Nysvenska Studier 19. 69-91.

Diderichsen, P. 1941. Satningsbygningen i Skaanske Lov. København: Munksgaard.

Diderichsen, P. 1946. Elementar dansk grammatik. København: Gyldendal.

Diderichsen, P. 1964. Sætningsleddene og deres stilling - tredive år efter. Danica, Studier $i$ dansk sprog til Aage Hansen 3. september 1964, 105-119.

Diderichsen, P. 1966. Helhed og struktur. København: G.E.C. Gads Forlag.

Dik, S.C. 1997. The theory of functional grammar, Part 1: The structure of the clause. Berlin: Mouton de Gruyter. DOI: 10.1515/9783110218367.

Drach, E. 1937. Grundgedanken der deutschen Satzlehre. Frankfurt: Moritz Diesterweg. Eisenberg, P., J. Peters, P. Gallmann, C. Fabricius-Hansen, D. Nübling, I. Barz, T. A. 
Fritz, R. Fiehler, 2006: Duden - Die Grammatik, vol. 4, 7. udgave. Mannheim: Bibliographisches Institut.

Gelderen, E. van. 2014. Clause structure. Cambridge: Cambridge University Press.

Givón, T. 2001. Syntax, an introduction. Volume 1. Amsterdam: Benjamins.

Hansen, E. 1977. Damonernes port. Stottemateriale til undervisningen i nydansk grammatik. København: Hans Reitzel.

Hansen, E. \& L. Heltoft. 2011. Grammatik over det danske sprog. København: Det Danske Sprog- og Litteraturselskab.

Harder, P. 2005. Lagdelt sætningsstruktur. Engberg-Pedersen, E., M. Fortescue, P.

Harder, L. Heltoft, M. Herslund \& L. Falster Jakobsen. 2005 (red.), Dansk, funk.tionel lingvistik - en helhedsforstaelse af forholdet mellem sprogstruktur, sprogbrug og kognition. http://lingvistkredsen.ku.dk/pdf/dfl/DFL-bog.pdf. Tilgået 14. august 2017.

Heltoft, L. 1986. Topologi og syntaks. En revision af Paul Diderichsens sætningsskema. L. Heltoft \& J.E. Andersen (red.), Satningsskemaet og dets stilling - 50 år efter, Nydanske studier og almen kommunikationsteori, NyS 16/17, 105-130. DOI: 10.7146/nys.v16i16-17.13345.

Heltoft, L. 1992. The topology of verb second and SVO-languages - a study in the sign functions of word order. Copenhagen studies in language 15. 13-64.

Hengeveld, K. \& J. Lachlan Mackenzie. 2008. Functional discourse grammar: a typologicallybased theory of language structure. Oxford: Oxford University Press. DOI: 10.1093/acprof:oso/9780199278107.001.0001.

Henriksen, C. 1986. Sætningsleddene og deres stilling - nogle år før - og flere år efter.

L. Heltoft \& J.E. Andersen (red.), Satningsskemaet og dets stilling - 50 år efter, Nydanske studier og almen kommunikationsteori, NyS 16/17, 210-228. DOI: 10.7146/nys. v16i16-17.13351.

Hjelmslev, L. 1972. Sprogsystem og sprogforandring. Travaux du cercle linguistique de Copenhague XV. København: Nordisk Sprog- og kulturforlag.

Jørgensen, H. 2000. Indforing $i$ dansk syntaks, Aarhus Universitet, www.hum.au.dk/engelsk/engsv/papers/joer00b.pdf. Tilgået 9. december 2016.

Lundskær-Nielsen, T. \& P. Holmes. 2010. Danish, a comprehensive grammar. London: Routledge.

McCloskey, J. 1997. Subjecthood and subject positions. L. Haegeman (red.), Elements of grammar. Dordrecht: Kluwer, 197-235. DOI: 10.1007/978-94-011-5420-8_5.

Matthiessen, C.M.I., K. Teruya \& M. Lam. 2010. Key terms in systemic functional linguistics. London: Continuum. 
Petersen, K.T. 2015. Udviklingen af inkorporation fra gammel-dansk til moderne dansk - fra umarkerede kasusformer til markeret artikelloshed og enhedstryk. Ph.d.afhandling, Aarhus Universitet.

Platzack, C. 1985. A survey of generative analyses of the verb second phenomenon in Germanic. Nordic journal of linguistics 8(1) 49-73. DOI: 10.1017/ S0332586500001256.

Platzack, C. 2010. Den fantastiska gramatiken. Stockholm: Norstedts.

Popper, K. 1994. The myth of the framework. London: Routledge.

Preisler, B. 1997. Handbook of English grammar on functional principles, 2. udg. Aarhus: Aarhus University Press.

Retskrivningsordbogen. 2012. 4. udgave. København: Dansk Sprognævn. www.dsn.dk/ro. Tilgået 9. december 2016.

Thomsen, O.N. 2002. Complex predicate formation and incorporation. Towards a typology. O.N. Thomsen \& M. Herslund (red.), Complex predicates and incorporation. A functional perspective. Travaux du cercle linguistique de Copenhague XXXII, 120-174. København: C.A. Reitzel.

Togeby, O. 2003. Fungerer denne satning? - Funktionel dansk sproglare. København: Gads Forlag.

Vikner, S. 1985. Parameters of binder and of binding category in Danish. Working papers in Scandinavian syntax 23. www.hum.au.dk/engelsk/engsv/papers/ vikn85a.pdf. Tilgået 9. december 2016.

Vikner, S. 1995. Verb movement and expletive subjects in the Germanic languages. Oxford: Oxford University Press.

Vikner, S. 1999. $V^{\circ}$-til-I flytning og personfleksion i alle tempora. Islensket mál 19. 81128. www.hum.au.dk/engelsk/engsv/papers/vikn99b.pdf. Tilgået 9. december 2016.

Vikner, S. 2007. Teoretisk og komparativ syntaks. H. Jørgensen \& P. Widell (red.), Det bedre argument - Festskrift til Ole Togeby, 7. marts 2007, 469-480. Aarhus: Wessel \& Huitfeld. www.hum.au.dk/engelsk/engsv/papers/vikn07a.pdf. Tilgået 09.12.2016.

Vikner, S. 2013. C-kommando, koreference og negative polaritetselementer i dansk. I.S. Hansen, T.T. Hougaard \& P. Widell (red.), MUDS 14 - 14. mode om udforskningen af dansk sprog, 467-484. www.hum.au.dk/engelsk/engsv/papers/ vikn13a.pdf. Tilgået 09.12.2016.

Wöllstein-Leisten, A., A. Heilmann, P. Stepan \& S. Vikner. 1997. Deutsche Satəstruktur. Tübingen: Stauffenburg. 